Nama: Rismawati

Nim: 90100118032

Ekonomi Islam A

\title{
Tokoh pemikir mercantilisme dan pegaruhnya terhadap perubahan sosial masyarakat
}

\section{Jean Bodin (1530-1596)}

Seorang Ilmuan berbangsa perancis, yang dapat dikatakan sebagai orang pertama yang secara sistematis menyajikan teori tentang uang dan harga. Terdapat dalam bukunya Reponse aux paradoxex de malestroit (1568) menurut Bodin, naiknya harga barang-barang disebabkan oleh lima faktor:

- Bertambahnya logam mulia, yaitu emas dan perak

- Praktek monopoli yang dilakukan oleh dua swasta maupun peran Negara

- Jumlah barang di dalam negeri menjadi langka oleh karena sebagian hasil produksi diekspor

- Pola hidup mewah kalangan bangsawan dan raja-raja

- Menurunnya nilai mata uang logam karena isi karat yang terkandung di dalamya dikurangi atau di permainkan

- Bodin sependapat dengan Machiavelli bahwa Negara mempunyai kekuasaan mutlak terhadsp warga Negara, karena warga negaraa berada diatas hukum.

- Menghadapi perilku amat mewah, Jean Bodin menekankan, jika jumlah cadangan yang berupa persediaan emas tersebut disimpan dahulu, dan pengeluaran dilakukan secara hemat dan berhati-hati maka inflasi akan terkendalikan.

2. Thornas Mun (1571-1641)

- Seorang saudagar kaya yang berasal dari Inggris. Banyak menulis masalah perdagangan inggris

- Salah satu karyanya yang terkenal adalah England Treasure by foreign Trade, memberikan sumbangan yang besar terhadap teori perdagangan luar negri.

- Menurut Mun, untuk meningkakan kekayaan Negara, cara yang biasa dilakukan adalah lewat perdagngan. Pedoman yag digunakan ialah nilai ekspor ke liat negeri harus lebih besar dibandingkan dengan yang diimpor Negara itu.

3. Jean Baptis Colbert

- Seorang pejabat Negara perancis dengan kedudukan sebagai menteri utama dibidang ekonomi dan keuangan dalam pemerinthan raja Louis XIV.

- Tujuan kebijakan yang dibuat Colbert lebih diarahkan pada kekuasaan dan kejayaan Negara daripada untuk meningkatkan kekayaan orang perorang.

- Ia merangsang penemuan-penemuan baru serta membangun industri-industri percontohan. Ia juga mendorong pengembangan ilmu pengetahuan dengan mendirikan akademi-akdemi, perpustakaan-perpustakaan dan pemberian subsidi-subsidi.

4. Sir Williarn petty (1623-1687)

- Pengajar di Oxford University, dan banyak menulis tentang ekonomi politik 
- Dalam hal uang, menurutnya uang diperlukan dalam jumlah secukupnya, tetapi lebih atau kurang dari yang diperlukan dapat mendatangkan kemudharatan

- Menurutnya harga untuk uang adalah bungamodal. Dengan demikian, semakin besar umlah uang beredar, maka bunga modal turun, hal ini akan memdorong kegiatan usaha.

- Ia berpendapat bahwa tingkat harga bervariasi proporsional dengan jumlah uang beredar.

5. David Hurne (1711-1776)

- sahabat Adam smith, sering berdiskusi mengenai perdagangan-perdagangannya terhadap ekonomi

- Bukunya adalah of balance of trade, yang membicarakan tentang harga-harga yang sebagian di pengaruhi oleh jumlah uang.

Dalam masa ini tidak hanya perdagangan dan perekonomian yang maju pesat, namun kemajuan dalam tulisan ekonomi juga maju baik dari segi jumlah maupun mutu. Antara Negara dan para pedagang tercipta suasan saling membutuhkan. Para raja membangun, memelihara dan menjamin keselamatan jalan raya untuk lalu lintas darat dan air srta mengahpus bea-bea khsusus. Pemerintah mendorong kelompok-kelompok pengusaha dengan memberikan subsidi dan hak monopoli. Perdagangan tidak hanya berkembang di Negara eropa saja, namun telah menyebar luas mencapai Timur tengah, setelah perang shalib. Kebijaksanaan-kebijaksanaan pada masa itu sangat mengabaikan sector pertanian, sehingga menimbulkan bebagai kritik. Lahirnya berbagai kritik ini merupakan pertanda awal lahirnya paham baru, yakni aliran fisiokrat. Tiga pokok pemikiran aliran merkantilisme adalah tentang neraca perdagangan dan mekanisme arus logam mulia, proteksi dan teori kuantitas uang. Ketiga pokok pemikiran ini terpusat pada satu doktrin merkantilisme, yakni neraca perdagangan yang menguntungkan. ${ }^{1}$

menurut kaum merkantilisme, kekayaan ekonomi terdapat pada logam mulia (emas) yang mendukung kekuatan suatu Negara bersama kemampuan militernya. apabila bahan baku dalam suatu Negara tidak mencukupi untuk pemenuhan kebutuhan maka Negara harus memiliki wilayah Negara lain sebagai Negara jajahan. ${ }^{2}$ ditegaskan bahwa padatnya penduduk merupakan sumber kekayaan yang tidak ternilai harganya dan apabila jumlah penduduk sedikit mereka akan mudah mencari nafkah dan akibanya mereka akan menjadi malas. sebaliknya dalam kondisi penduduk yang padat, maka mau tidak mau penduduk harus bekerja keras dalam hal itu akan merangsang timbulnya pikiran yang lebih cenderung kea rah kegiatan ekonomi dan industri. ${ }^{3}$

\footnotetext{
${ }^{1}$ Firmansyah, "sejarah pemikiran ekonomi". 2007, hlm 9-10

${ }^{2}$ suprapto, M.S. "perkembangan pemikiran ekonomi".

${ }^{3}$ subair, s." relevansi teori Mhatus dalam diskursus kependudukan kontemporer, jurnal dialektika, Vol. 9 No. 2, 2018, hlm 98
} 


\section{DAFTAR PUSTAKA}

Subair, S. (2018). relevansi teori Mhatus dalam diskursus kependudukan kontemporer, jurnal dialektika, 9(2). hlm 98

Firmansyah, F. (2007). Sejarah pemikiran ekonomi. hlm 9-10

Suprapto, M. S. Perkembangan Pemikiran Ekonomi dan Kontroversi. 